\title{
GOVERNMENT EXPENDITURE ON SCIENTIFIC RESEARCH, 1962
}

$\mathrm{T}$ HE report of the Council for Scientific and Industrial Research for the year $1962 *$ records gross expenditure in the year ended March 31,1962 , of $£ 16,691,172$, compared with $£ 14,467,278$ in the previous year, and reduced to $£ 14,378,202$ by various receipts from industry and other sources for services rendered, of which $£ 1,120,677$ was from other Government departments and $£ 858,170$ from industry, $£ 214,143$ being received by the National Physical Laboratory. The net increase on 1961 was $£ 1,619,022$, and of this, $£ 258,922$ is on account of the National Lending Library for Science and Technology, which figures for the first time as a separate item (gross expenditure, $£ 304,249$ ) in the summary of expenditure. The staff again increased, from 6,224 to 6,525 . Grants for special researches rose to $£ 2,275,060$, compared with $£ 1,495,469$ in 1961 , and contributions to the European Organization for Nuclear Research remained about $£ 1,359,000$, while receipts reduced the contribution of $£ 198,800$ to NATO and the Organization for European Co-operation and Development scientific schemes to $£ 63,722$.

Postgraduate training awards amounted to $£ 1,289,903$ ( $£ 1,105,415$ in 1961) and the 1,604 new studentships, an increase of 9 per cent, brought the number current to 3,478. Research fellowships increased from 54 in 1961 to 92 in 1962 , and there are now 133 current. Of 51 awards for study abroad taken up, 23 were studentships and 28 fellowships, while 8 studentships and 16 fellowships were awarded to assist young British scientists returning from North America; 35 candidates with the diploma in technology obtained awards, compared with 11 in 1961. Of the 3,019 current research studentships, 413 were in biology and biochemistry, 205 in chemical engineering and metallurgy, 899 in chemistry, 128 in electrical and 203 in other fields of engineering, 214 in geology, 57 in the human sciences, 260 in mathematics, and 640 in physics. The advanced course studentships were distributed mainly in mathematics (88), physics (75) and engineering (other than electrical) (70), with 39 in chemical engineering and metallurgy, 29 in human sciences, 28 in biology and biochemistry, 22 in geology, 20 in electrical engineering and 15 in chemistry. All the 73 first-year studentships were again in chemistry, and of the 115 research fellowships, 56 were in chemistry, 29 in physics and 25 in biology and biochemistry, with 10 in geology.

Grants for special researches totalled 724, of which 321 were new, amounting to $£ 9,881,252$ in the year ended March 31,1962 ; of these, 59 in nuclear physics totalled

* Department of Scientific and Industrial Research. Report of the Research Council for the Year 1962. Pp. 62. (Cmnd. 2027.) (London: H.M.S.O., 1963.) 4s. net. (See also p. 207 of this issue of Nature.)
$£ 3,870,624,17$ in astronomy, $£ 1,045,796,121$ in technology, $£ 1,024,768$, and 165 in chemistry, $£ 957,551$. The 79 grants in low-temperature and solid-state physics totalled $£ 688,267,100$ grants in biology totalled $£ 535,417$, 33 in space research, $£ 520,926,58$ in geology and geophysics, $£ 469,689,50$ in the human sciences, $£ 419,601$,

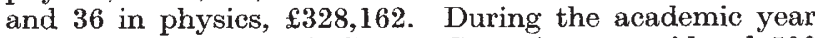
1961-62, the Research Grants Committee considered 500 applications for grants with a total value of $£ 4,204,000$, compared with 447 applications valued at $£ 3,156,000$ in the previous year, and made 390 grants with a total value of $£ 2,313,000$, compared with 362 amounting to $£ 1,961,000$ in 1960-61. In addition, five grants were awarded for new major capital projects: $\mathfrak{\$ 3 3 4 , 2 0 0}$ to the University of Cambridge for construction of a radio-telescope for research under Prof. M. Ryle; $£ 301,000$ to the University of Manchester for construction of a 125 - ft. steerable radiotelescope for research under Sir Bernard Lovell; and three grants totalling $£ 1,188,000$ for nuclear reactors for the University of London as a whole, the Universities of Manchester and Liverpool jointly and the Scottish and Northern Ireland universities. The Human Sciences Committee considered 36 applications with a total value of $£ 232,000$ and made 27 awards to the value of

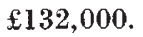

With the exception of building research, which decreased slightly from $£ 785,413$ gross in $1960-61$ to $£ 781,037$ gross in 1961-62, and the Geological Survey and Museum, which decreased from $£ 586,640$ to $£ 578,969$ gross, the increased expenditure was distributed fairly generally over all branches of the Department's work. However, an unexplained jump in receipts by the Tropical Products Institute from $£ 22,300$ to $£ 399,472$ converted the increased total expenditure on the Institute of $£ 229,751$ into a credit of $£ 169,721$, an anomaly that seems to call for comment. The major increases are in the expenditure of the National Physical Laboratory (£2,033,109 gross; $\mathfrak{E} 1,787,542$ in $1960-61$ ), the National Engineering Laboratory (£924,978; £811,164); the National Chemical Laboratory (£409,887; £384,073); road research $(£ 970,403$; $£ 872,805) ; \quad$ radio research (£320,413; $£ 239,957$ ). For fire research the corresponding figures are $£ 164,438$ and $£ 156,130$; for forest products research, $£ 194,619$ and $£ 185,985$; hydraulics research, $£ 232,661$ and $£ 203,931$; the Torry Research Station, $£ 226,696$ and $£ 215,192$; the Warren Spring Laboratory, $£ 471,181$ and $£ 453,985$; water-pollution research, $£ 183,550$ and $£ 165,336$; and for the Government Chemist's Laboratory, $£ 491,215$ and $£ 460,257$. Expenditure on headquarters administration decreased from $£ 758,126$ in $1960-61$ to $£ 615,536$, or slightly below the 1959-60 figure.

\section{EDUCATION IN MATERIALS SCIENCE}

\begin{abstract}
$\mathrm{T}$ HE first conference on "Education in Materials Science" and technology in the United Kingdom was held in Banbury during May 18-19 under the general chairmanship of Mr. L. Holliday (Shell Chemical Co., Ltd.). The conference was arranged by the Steering Committee of the Working Party on Materials Science and Technology, set up by the Institution of Chemical Engineers. Some thirty representatives from universities, colleges of advanced technology and industry were invited.
\end{abstract}

The first session dealt with the situation in materials science in the United States and in Britain and went on to consider possible starting points for materials science courses and research in universities. Sir Harry Melville, secretary of the Department of Scientific and Industrial Research, introduced the subject of the conference and emphasized its importance not only in universities and colleges but also in industry and Government scientific establishments. It was of immediate concern to the Department of Scientific and Industrial Research, which 